
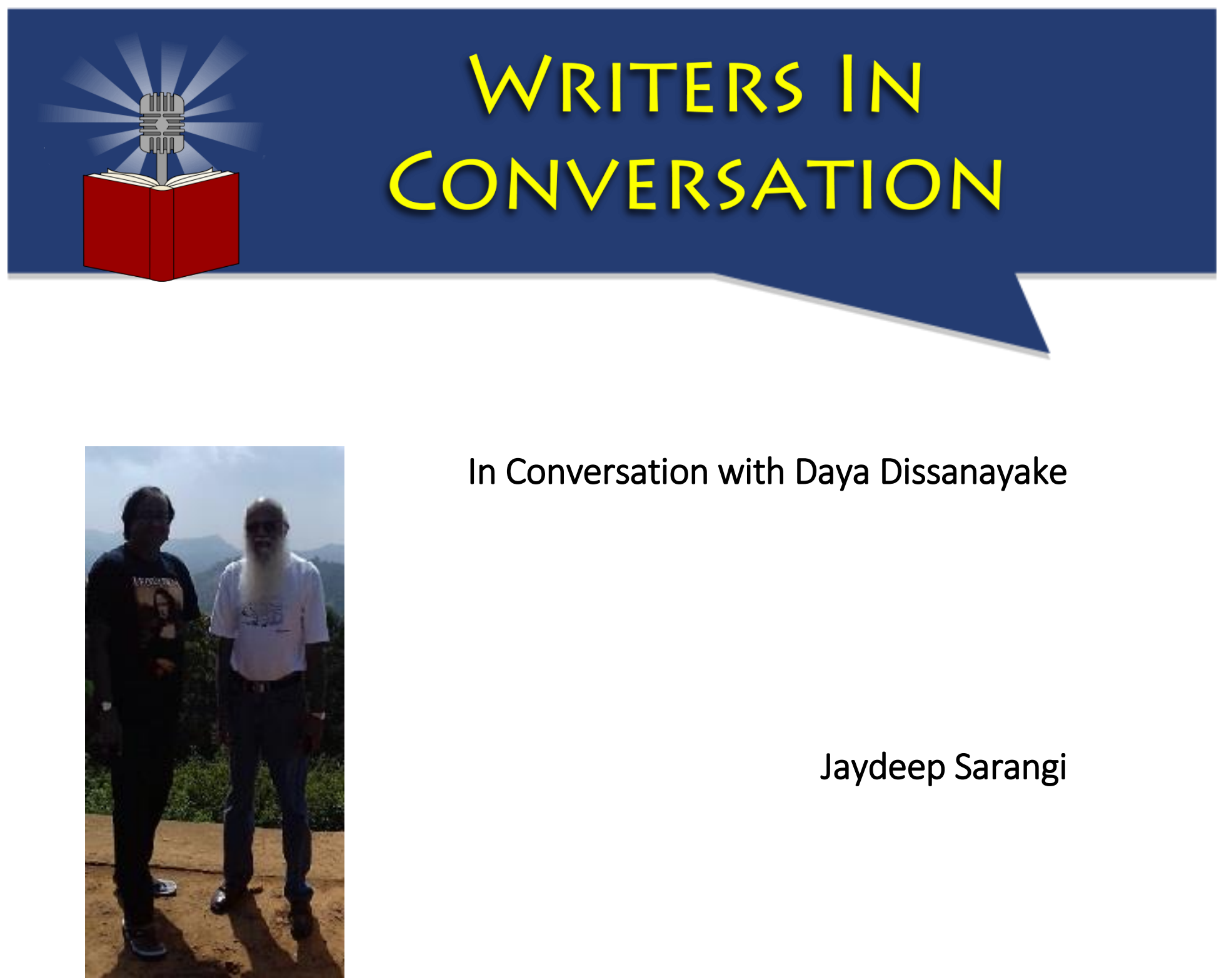

In Conversation with Daya Dissanayake

Jaydeep Sarangi with Daya Dissanayake

\title{
Jaydeep Sarangi
}

Daya Dissanayake (born 8 March 1947) is an award-winning bilingual Sri Lankan novelist, poet and feature writer. His work spans nine novels in English, six novels in Sinhala, a collection of poems, and numerous articles in newspapers, journals and magazines. He is the author of the first e-novel in Asia, The Saadhu Testament (1998), and the first e-novel in Sinhala, Vessan Novu Wedun (2003). He is the only Sri Lankan writer to receive the Sri Lankan State Literary Award for the best English novel thrice and was awarded the SAARC Literary Award in 2013. Being the first Sri Lankan to release his work online and for free access, he is often seen as one of Sri Lanka's earliest and most vocal advocates for the e-book format, copy left and Creative Commons.

This interview was conducted at Yercaud, a hill station in Salem District, in Tamil Nadu, India. Some answers were formed during the e mail exchanges.

Q. Would you please share with us about your childhood?

A. I was born and grew up in the southern port city of Galle in Sri Lanka. I was the eldest in a family of 6 (3 sisters and 2 brothers). My entire formal education was at a Jesuit school in Galle, St. Aloysius' College, where I studied up to GCE Advanced Level (12 ${ }^{\text {th }}$ grade) in the bio- 
science stream. Since then my universities had been all the libraries I had the good fortune to have access to, and later the World Wide Web. Most of my childhood was spent by the sea, and my friends and neighbours were from all races, creeds and castes, speaking in Sinhala, Tamil and English. My father who worked as a clerk for a leading lawyer in Galle, was a voracious reader, and he introduced me to the world of books. I was able to pass on the habit to my son and daughter, who in turn have passed it down to their children. My daughter is a journalist, writer and translator, while my grand daughter published a book of stories when she was ten years old, both are writing in English.

Q. What are your current writings?

A. I write an occasional poem, when an idea comes into my head. At present I am doing a study of the development of beliefs and traditions in South Asia from the time of the Indus Civilization.

Q. You are writing a mammoth book on King Ashoka. Why did you think of this book?

A. I have completed my work on King Ashoka, which I consider as a critical study, because I realised that we really do not know anything about such a famous character. There are so many research studies done over the past two centuries, in addition to the ancient chronicles. And yet the more I started reading on Ashoka, more questions came to mind without any answers for the questions I already had. I hope my book will encourage historians, archaeologists, linguists and anthropologists to try to find answers.

Q. Can a writer be free from religion?

A. I do not know about other writers, but I really do not know what my religion is, because so far I do not think anyone has been able to give a definition of religion acceptable to all human beings. I have a regard and respect for all faiths, because I believe they were all founded, and continue to be for the good of mankind. I am labelled a Buddhist because the state and society label us at birth, and I have been exposed more to Buddha Dhamma from my childhood.

Q. Your second book, The Saadhu Testament, is the first electronic novel by an Asian author. How did you get the idea?

A. I have always believed that what we create, what we write, should be shared with all, and we do not have a right to claim any ownership. When the internet opened the whole universe to us, I thought that would be the future for literature. My son, Raditha, who is a software consultant, encouraged me to publish my second novel on the web, after I won the State Award for my first novel Katbitha. Raditha developed the website as saadhu.com (we had to settle for saadhu, the usual term sadhu had already been taken) because of the title of

In Conversation with Daya Dissanayake. Jaydeep Sarangi. Writers in Conversation Vol. 6 no. 1, February 2019. journals.flinders.edu.au 
my novel, and I have continued to use the site for my blog, features and to release a few novels for free reading.

\section{Q. What are the themes of The Saadhu Testament?}

A. The Saadhu is based on present day religious figures in South Asia, who are considered as Miracle Men by many people. I believe they are also doing a service, fulfilling a need of mankind, for external forces and assistance in their life, for health, wealth and power. I do not condemn them or criticise their action.

\section{Q. Did you read Indian authors in English?}

A. Yes, I do read Indian writers in English, except the diaspora writers, other than Rushdie. Whenever I get an opportunity, whenever I visit India I always buy a few books, and now I also have an opportunity to read their soft copies. Unfortunately we in Sri Lanka do not have access to good writings from India, because booksellers are interested in popular or best sellers only, and not the best books. I also get an opportunity to read Indian poetry in English because I know many Indian poets.

\section{Q. Who are the important contemporary voices from your land?}

A. We have a long history of literary works, going back at least for over 2000 years. Literary works in English had begun only about a 100 years ago. We have produced great writers in the last century, like Ediriweera Sarachchandra, whose novels were published by UNESCO. Martin Wickramasinghe, another bilingual writer, whose books have been translated into Russian. But other great Sinhala writers are not known outside our country, because they wrote in Sinhala, and the works were not translated into English. A few names are Mahagama Sekara, Simon Nawagattegama, Gunadasa Amarasekara and Sugathapala de Silva. Among the contemporary writers in English, we have Punyakante Wijenaiyake, Kamala Wijerathne, Yasmine Gooneratne, and Carl Muller.

\section{Q. Why are we not aware of authors from our neighbouring countries?}

A. South Asia has many languages and the only link is English. Not many literary creations are published in English or in translation. Even the books available in English do not cross borders, so we do not get an opportunity to read authors of our neighbouring countries.

When the SAARC (South Asian Association for Regional Cooperation) Cultural Centre was formed, and it was located in Sri Lanka, we had high hopes for South Asian Literature. They started some ambitious projects, publishing anthologies of poetry and short stories, from all SAARC countries, translated into English, and also another project to translate the great classics of each country into English. Unfortunately over the past four years all projects came to a standstill and we do not know what the future will bring. I have been fortunate to 
meet and interact with authors from other countries, thanks to social media and also numerous conferences organised by literary bodies in India.

Q. Did the popularity of cricket make an impact on writing?

A. Cricket has become a part of life. That is why Shehan Karunaltilaka's Chinaman became a hit, and even won the DSC Prize for South Asian Literature. Probably the only novel by a Sri Lankan known to many in India.

Q. How about the cricket autobiographies there? Are they popular?

A. I think it suffers the same fate as all books in our country, because the reading habit is almost dead, destroyed by television, mostly, and also by the high cost of books in our country.

Q. You stated clearly about your fascination for buddha dhamma, as explained by Ajhan Buddhadasa, 'being peaceful and useful.' Did you write about this?

A. I quote this phrase because it sums up the Buddha Dhamma in just four words. What has happened today is that the original Dhamma has been submerged in millions of words, each word adding to the confusion already caused by the various interpretations of the original words. I have touched on this often in my writings, even my poetry.

Q. Why did you write in English?

A. Our native language Sinhala, is found only in Sri Lanka, and spoken by about $\mathbf{1 5}$ million people. As I believe that what we write need to be shared, English is the only medium I could use. But I have written most of my novels and poetry in Sinhala too.

Q. What is the condition of use of English there?

A. English is the second language, or the bridge between Sinhala and Tamil, the two native languages, and for communication with the outside world.

Q. Did you read the epics of India?

A. I have read most of the Indian epics, but only in translation in English.

Q. How do you perceive the character Ravana?

A. When there are over $\mathbf{3 0 0}$ different versions of Ramayana, we in Sri Lanka are looking only at Valmiki's version, wanting to believe that the Ravana mentioned is the historical Ravana of Lanka. There is speculation that there had been a historical Ravana in Lanka, but if he was the

In Conversation with Daya Dissanayake. Jaydeep Sarangi. Writers in Conversation Vol. 6 no. 1, February 2019. journals.flinders.edu.au 
Ravana of Valmiki, it cannot be confirmed in any way. No archaeological evidence has been discovered in Sri Lanka about Ravana or Sita or the battle with Rama.

Q. Which one is your best work so far?

A. They are all my creations and I love them all, equally. Only my readers could judge if they are good or if some are better.

Q. You have been writing for more than 35 years. Is there any change of style or theme of your writing?

A. Though I had written a few poems and short stories when I was young, I began my first novel only in 1994, which took me four years to write. That is because I had to do a lot of research, for this story based around the tenth century. Over the years my writings would have changed with age and new knowledge, probably leading towards more themes on peace, harmony and the environment.

Q. Can writing change a society?

A. I believe that writing could change society. At present most modern popular writing is thriving on violence and the dark side of humanity. We should strive for writings that highlight peace and harmony, and love not only for humanity, but all life on earth. I use the term Subashitha Sahitya, ${ }^{1}$ for what we need in our literature.

Q. What is your latest book? What is it all about?

A. My latest book, as I mentioned earlier is the critical study on Ashoka. If you mean my last novel, it was The Clone, published a few years ago. I called it a historical novel from the future. The protagonist is a human clone, living a hundred thousand years from, now, tracing the human history from prehistoric times, trying to understand how the human race vanished from the face of the earth sometime during the twenty-first century.

Q. What are significant journals and magazines you are attached to in Srilanka now? Any good literary associations in India you are attached to?

A. When the reading habit is dead, there cannot be any significant journals. There is a periodical publication by the English Writers' Cooperative, to which I sometimes contribute. I wrote a regular column to the Daily News for over 5 years, on the theme Life into Arts, and a column to a Sinhala paper. At present I write a few articles for both the English and Sinhala papers, but not on a regular basis.

\footnotetext{
${ }^{1}$ A Sinhala term from Sanskrit, meaning 'well-written literature'.
}

In Conversation with Daya Dissanayake. Jaydeep Sarangi. Writers in Conversation Vol. 6 no. 1, February 2019. journals.flinders.edu.au

\section{ARCHIVED AT FLINDERS UNIVERSITY: DSPACE.FLINDERS.EDU.AU}


I was attached to the Foundation of SAARC Writers and Literature for many years. I have guest edited the issue on Sri Lanka of MargAsia by the Centre for Asian Studies in Bhubaneshwar, Odisha. I have contributed to other journals like The Equator Line by Plaimpsest, and The Teesta Review. I am also in the editorial board of the Bangladesh journal Bengal Lights.

\section{Q. Can creative writing be taught ?}

A. I don't believe creating writing could be taught. It is like teaching to ride a bicycle. One has to do it by oneself. Someone could assist you or guide you or make suggestion. It has to come from within, and it would be unique to each writer, just like with singing. Continuous reading also helps, to improve one's language, spelling, and grammar. It also sharpens one's mind, and opens it to look at the world from different angles. It is the practice one gains by continued writing which matters.

Q. What are the roles of literary festivals? Is there a literary festival in Sri Lanka?

A. Literary Festivals have become more a festival only and sometimes a business only. Some festivals are with a financial motive only, either fleecing the delegates, as an opportunity to sell books, hotel rooms and services. Other festivals are to give an opportunity to graduate students and young academics to present their papers, because they need the certificates issued confirming their paper presentation. The genuine spirit of a literary conference is lost and the only advantage is the opportunity to meet fellow writers from around the world. There had not been a real International Literary Festival in Sri Lanka for ages, either by the ministry of Culture, SAARC Cultural Centre or any of the universities. Attending festivals in other countries is also not easy, because there is no one to sponsor the air travel and accommodation.

Jaydeep Sarangi is an author, editor, translator and critic of multiple works and publications on Australian literature, Indian writing in English, postcolonial studies and the Dalit literary movement in India. He has also travelled to several universities as a resource person (and a poet) on postcolonial studies, poetry, and Indian literature in the context of world literature. He has delivered keynote, plenary address and invited talks at different Indian and foreign universities and read poems including University of Udine, University of New South Wales, Wollongong University, Rezeszow University, Pedagogical University, Flinders University, University of South Australia, Adelaide University and East Anglia University. He is currently the principal of New Alipore College, Kolkata. He is the Vice President of Guild of Indian English Writers Editors and Critics (GIEWEC) and the Secretary of Intercultural Poetry and Performance Library, ICCR, Kolkata. He guest edited three issues for the Muse India.

In Conversation with Daya Dissanayake. Jaydeep Sarangi. Writers in Conversation Vol. 6 no. 1, February 2019. journals.flinders.edu.au

\section{ARCHIVED AT FLINDERS UNIVERSITY: DSPACE.FLINDERS.EDU.AU}

